\title{
THE ROLE OF ENTREPRENEUR COMPETENCIES IN THE DEVELOPMENT OF RURAL AREAS
}

\section{Tetiana Balanovska, Full Professor'; Olga Gogulya, PhD, Associate Professor'; Barbara Wyrzykowska, $\mathrm{PhD}^{3}$}

1,2 Faculty of Agricultural Management, National University of Life and Environmental Sciences of Ukraine

${ }^{3}$ Faculty of Economic Sciences, Warsaw University of Life Sciences - SGGW

\begin{abstract}
The article substantiates that entrepreneurship is the basis of the country's economy, a prerequisite for the revival of rural areas. It represents environmental factors that impede the formation of a competitive business environment in the Ukraine, and, accordingly, the achievement of indicators of efficiency of entrepreneurial activity. The essence of competence of the entrepreneur and its components is also considered. Different points of view of scientists are generalized and a list of competencies, which should be owned and developed by an entrepreneur in the course of his/her activity in order to harmoniously grow as a socially responsible person is also presented in the paper. The expediency of forming entrepreneurial competence in the process of vocational training of young people to life in society, their future activity in new market conditions, as well as the logical sequence of using the skills and abilities of an entrepreneur through the implementation of key competencies is substantiated. The methodical aspects of assessing the level of competence of the entrepreneur are provided. The results of this will allow to develop directions and measures for improving the process of forming the entrepreneurial competence of employees, increasing the quality of the work force, and providing competitive advantages through the use of human resources in the agricultural sector of the economy.
\end{abstract}

Keywords: entrepreneurship, competency, entrepreneur, rural areas

JEL code: L2, M5

\section{INTRODUCTION}

The dynamic conditions of the modern world make entrepreneurial activity in any country of the world act as a driving force that generates national wealth by creating jobs, increasing GDP, stimulating competitiveness and innovation potential of a country's economy. Entrepreneurship, in the agrarian sector of the economy, plays an extremely important role in ensuring food security, the evolution of commodity production, the development of rural areas and raising the welfare of the rural population.

However, for a long period of time, most governmental initiatives focused on improving the manage-

${ }^{1}$ Corresponding author: Heroyiv Oborony 15, 03040 Kyiv, Ukraine, balanovskaya@nubip.edu.ua, +380 679672222

${ }^{2}$ Corresponding author: Heroyiv Oborony 15, 03040 Kyiv, Ukraine, ogogulya@ukr.net, +380(097) 9459014

${ }^{3}$ Corresponding author: Nowoursynowska 166, 02-787 Warsaw, Poland, barbara_wyrzykowska@sggw.pl, +4822 510897437 
ment of rural areas in Ukrainian society face major challenges. This concerns the implementation of programmes for subsidizing housing construction in rural areas, financial incentives for farms and social initiatives aimed at developing rural infrastructure, etc. The solution of the above-mentioned problems is hampered by the lack of adaptability of entrepreneurs and entrepreneurs of agricultural enterprises to the conditions of a competitive environment, outdated approaches to personnel work, management, assessment and the promotion of personnel, and a lack of work-out methodological tools for the development of entrepreneurial skills in the agrarian sector of the economy.

\section{THEORETICAL BACKGROUND}

The study of entrepreneurship as a social phenomenon is devoted to a large number of treaties, monographs and textbooks of famous classics of economic doctrines R. Cantillon, M. Weber, P. Drucker, K. Marx, A. Marshall, F. Knight, A. Smith, J. Schumpeter and others. The directions of solving the problems of youth professional training in entrepreneurship; the interpretation of the concepts of 'competence', 'professional competence', 'entrepreneurial competence' and the structure of entrepreneurial competence of specialists are disclosed in the research of N. Balovsiak, Yu. Bilova, M. Boiko, N. Boliubash, V. Cherevko, T. Furman, V. Maykovska, N. Pasichnyk, V. Prykhodko, L. Robles, M. Strelnikov, M. Zárraga-Rodríguez, and many others.

However, the analysis of scientific work proves that little attention is paid to the study of the role of an entrepreneur's competence in the development of rural areas and the peculiarities of the formation of respective competencies in the process of educational preparation and practical activity.

\section{STATEMENT OF THE PROBLEM}

The purpose of this study is to determine the role of entrepreneurs in the development of rural areas and to develop methodological guidelines for determining the level of competence of an entrepreneur.

\section{METHODOLOGY}

In the course of the study, a dialectical method of knowledge was used to collect, analyse, evaluate information and form conclusions, as well as monographical - in the process of systematization of approaches to structuring competencies, the definition of their criteria and classifications. The determination of the level of competence of an entrepreneur is proposed to be carried out with the use of an expert assessment, using the classical structure of expert research.

\section{RESULTS}

Entrepreneurship involves the presence of an environment necessary for its effective functioning. The decline of rural areas in the Ukraine is a confirmation of the absence of favourable conditions for conducting entrepreneurship, the lack of an organizational mechanism based on the orientation of the future specialist in achieving the best result in economic activity based on the competitiveness of products, personnel resources and technologies.

Unfavourable trends in the deterioration of the quality of life in rural areas are reflected in various areas of public life. According to official statistics, only since the last census in the Ukraine (5 December 2001 ), by 2017 , the rural population has decreased by $17.5 \%$, which is almost twice the corresponding rate of urban depopulation $(9.5 \%)^{4}$. For the Ukraine as a whole, and for its rural areas in particular, the regressive type of age structure of the population, in which the share of persons aged 50 and older is slightly higher than the share of children (under the age of 14) is common. At the same time, during the last 15 years, for the virtually unchanged share of people aged 15-49 in the rural population of the Ukraine, there is a significant reduction in the proportion of children, which, by the beginning of 2016, is more than twice as low as the proportion of persons aged 50 and older (Borshchevsky, Mahas and Tsymbalista, 2017). Thus, against the backdrop of deepening of general tendencies of population aging and the corre-

\footnotetext{
${ }^{4}$ State Statistics Service of the Ukraine website http://www.ukrstat.gov.ua.
} 
sponding increase in mortality, there is a violation of the natural reproduction of the population in general and the inhabitants of rural areas in particular.

In addition to the influence of indirect environmental factors that determine the conditions of an entrepreneurial environment, the problem of low awareness and immediate resolution is the problem of low motivation to reveal entrepreneurial initiative and an inadequate level of formation of readiness for entrepreneurship among young people and graduates of educational institutions.

Entrepreneurial competence as a component of professional competence that ensures the focus of a future specialist's activity on success in business and further self-realization of professional activity in the field of entrepreneurship, requires productive economic thinking (understanding basic economic and financial categories, possessing skills of effective economic activity, knowledge of current economic legislation), developed motivation to reveal entrepreneurial initiative, the ability of the individual to self-realization, self-improvement and social responsibility. New products and services can only be generated when they are generated through the practical realization of knowledge, skills and understanding of innovative technologies of entrepreneurs who own a high competence potential.

Today's challenges require an adequate response of specialists in the agrarian sector, and these are directly inhabitants of rural areas, who have expertise in the peculiarities of growing agricultural products, are aware of the dependence on natural and climatic conditions, are owners of land plots etc., and on innovative technologies that are increasingly becoming a prerequisite for the development of the industry, the country and the world food market. Thus, within the framework of the Techstars Startup Week Kyiv 2017, which brought together entrepreneurs from different industries to find new solutions and jointly realize their capabilities, new technologies that were actively used by farmers in developed countries as well as some Ukrainian agricultural producers were considered. Among the agricultural equipment available to agricultural producers, drone and unmanned aerial vehicles, farmland meteorological stations, modern irrigation systems, satellite monitoring and so on should be noted (BusinessViews, 2017).

Since an entrepreneur can acquire an overwhelming number of competencies in the course of their activity and development, the issues of professional preparedness of young people for life in society and their activity in new market conditions are becoming more and more relevant. Particularly relevant conclusions were highlighted by us in previous studies (Balanovska and Gogulya, 2017) regarding the issue of the peculiarities of the formation of future specialists (managers) of the agrarian sector in the context of the needs of the modern labour market, which make it possible to distinguish entrepreneurial professional competencies in rural areas. And also, in previous studies, the following 10 human skills most demanded by 2020 when working in the field under the influence of rapid development of technological process were outlined, namely: solving complex problems; critical thinking; creative abilities; managerial talents; coordination with others; emotional intelligence; the ability to reason and make decisions; service orientation; negotiating skills; cognitive flexibility (Gogulya, 2017).

The formation of entrepreneurial competence in the modern manager of an agricultural enterprise as a combination of personal and business qualities, skills, knowledge, a certain model of behaviour, the possession of which helps to successfully solve various business tasks and achieve high performance is a prerequisite for a high level of competitiveness. Unlike quality, which reflects a certain level of potential, the category of competitiveness reflects the ability of an entrepreneur to realize his/her competency potential. Therefore, the competitiveness of a specialist in the agrarian sector is determined not only by a certain level of competence potential, but also by the ability to realize this potential in practice, as well as the availability of appropriate conditions for this (Wyrzykowska, 2016).

Figure 1 reflects the logical sequence (step by step) of the use of skills (as a set of skills and abilities) of an entrepreneur through the implementation of key competencies in the context of rural development.

The analysis of overall professional competence of a person-entrepreneur will help to assess the 


\begin{tabular}{|c|c|}
\hline Stages of using the skills of the entrepreneur & Key competences \\
\hline $\begin{array}{l}\text { 1. Ability to choose and create a business strategy } \\
\text { for the development of rural areas }\end{array}$ & $\begin{array}{l}\text { The combination of economic, } \\
\text { political competence and moral } \\
\text { legitimacy }\end{array}$ \\
\hline $\begin{array}{l}\text { 2. Ability to use the latest agrotechnologies } \\
\text { and achievements in energy-saving } \\
\text { agricultural practices, bioengineering and so on }\end{array}$ & $\begin{array}{l}\text { Specific professional competencies } \\
\text { (including control and analytical, } \\
\text { organizational and managerial, } \\
\text { information and communication) }\end{array}$ \\
\hline $\begin{array}{l}\text { 3. Ability to legalize your business, open and register } \\
\text { your own business in the agrarian sector } \\
\text { of the economy }\end{array}$ & Legal competence \\
\hline $\begin{array}{l}\text { 4. Ability to form a team (team), pick up like-minded } \\
\text { people, conduct value orientation regulation, } \\
\text { motivational encouragement }\end{array}$ & Managerial competence \\
\hline $\begin{array}{l}\text { 5. Ability to investigate the agro-food } \\
\text { market in order to promote a product or service }\end{array}$ & $\begin{array}{l}\text { Sociological, psychological } \\
\text { and pedagogical competence }\end{array}$ \\
\hline $\begin{array}{l}\text { 6. Ability to present yourself as an entrepreneur and the results } \\
\text { of his work. Ability to negotiate with business partners, } \\
\text { convince, inspire an idea, defend your own point of view, } \\
\text { ability to offer and sell goods and services }\end{array}$ & $\begin{array}{l}\text { Psychological-pedagogical } \\
\text { competence }\end{array}$ \\
\hline
\end{tabular}

Figure 1. The role of entrepreneur competencies in the development of rural areas

Source: own elaboration.

business and professional features of an entrepreneur in the agrarian sector of the economy:

- economic competence is differentiated depending on the specialization of the entrepreneur and should include an assessment of the ability to apply different types of analysis of key economic concepts;

- political competence and moral legitimacy implies an understanding of the nature of the basic social functions and organizational structure of modern states, the principles and forms of democracy, the nature of the interaction between different branches of government, the role of political parties in society and economic processes in the country and its borders;

- legal competence is formed in the course of basic vocational training, which relates to the main branches of law and is based on the skills of its professional application in various spheres of economic activity;
- sociological competence is connected with the awareness of the entrepreneur of the concept of the social structure of modern society, its dynamics and influence on political and socio-economic processes;

- managerial competence includes knowledge of management methods, value orientation regulation, integrated management of labour motivation, development of creative potential, etc.;

- psycho-pedagogical competence is the basis for effective communication contacts, when it is necessary to understand people, their interests, motives and intentions, to find an individual approach to them.

Mastering such knowledge and skills should be a benchmark for the basic training of modern entrepreneurs and meet the requirements of the qualities of entrepreneurs.

It is the interpretation of the notion of 'entrepreneurship' that outlines clear benchmarks for under- 
standing the role of entrepreneur competencies. Here is a classical interpretation of 'entrepreneurship' as a special type of activity, which is based on a number of prerequisites and requirements: the entrepreneur initiates the combination of land, capital and labour into a single process of production of goods or services; the entrepreneur takes on the complex task of making key decisions in the process of producing goods or services that determine the course of the enterprise; the entrepreneur assumes responsibility for the results of the production of investment, expenses of time and labour, business reputation and their future profits; the entrepreneur acts as an innovator, who commercially introduces the new products, new production technologies, new forms of enterprise organization, etc. (McKonnell and Brue, 2003).

According to research, the scholars (Robles and Zárraga-Rodríguez, 2015) present 20 competencies that are important and influential in achieving business efficiency: risk aversion, autonomy, information search and analysis, work quality, communication, confidence, self-development, social network development, dynamism, change management, initiative, innovation, integrity, leadership, self-control, results orientation, social mobility, negotiation, troubleshooting, responsibility and teamwork. However, some researchers consider the above list to be too detailed and agree on the desirability of outlining the following: risk aversion, initiative, responsibility, dynamism, troubleshooting, information search and analysis, results orientation, change management and quality of work.

On the basis of the analysis of scientific works of Ukrainian and foreign scholars (Bilova; 2013; Robles and Zárraga-Rodríguez, 2015; EntreComp, 2016; Maykovska, 2017), different points of view are summarised and a list of competencies to be owned and developed by an entrepreneur for harmonious growth as a socially responsible person, professional manager of an organizational entity or business owner are formulated (Table 1).

In determining the level of entrepreneurial competence among graduates of educational institutions,

Table 1. List of competencies of the entrepreneur

\begin{tabular}{|c|c|}
\hline $\begin{array}{ll}\text { 1. } & \mathrm{Ho} \\
\text { 2. } & \mathrm{Pu} \\
\text { 3. } \mathrm{To} \\
\text { 4. } \mathrm{Co} \\
\text { 5. } \mathrm{Th} \\
\text { 6. } \mathrm{Fr} \\
\text { 7. } \mathrm{Th} \\
\text { 8. } \mathrm{Inv} \\
\text { 9. } \mathrm{Ri} \\
\text { 10. } \mathrm{Cr} \\
\text { 11. Inn } \\
\text { 12. Re } \\
\text { 13. Re } \\
\text { anc } \\
\text { 14. } \mathrm{Ab} \\
\text { of } \\
\text { 15. } \mathrm{Ex} \\
\text { in } \\
\text { 16. } \mathrm{Th} \\
\text { fee } \\
\text { 17. Le } \\
\text { for }\end{array}$ & $\begin{array}{l}\text { usiness idea and forms of entrepreneurial } \\
\text { conduct constructive business dialogue } \\
\text { re problems in the field of entrepreneurial } \\
\text { he progress and results of entrepreneurial } \\
\text { emotional state in the situation of finding } \\
\text { jects } \\
\text { enterprise. Ability to create a team of like- } \\
\text { th ethical standards of treatment, greetings, } \\
\text { iness contacts } \\
\text { hotion } \\
\text { d cash flow management; justification of } \\
\text { f funding and attracting investment } \\
\text { nd entrepreneurial activity and collective } \\
\text { and ethics of labour relations }\end{array}$ \\
\hline
\end{tabular}

Source: own elaboration. 
rural residents, those interested in starting entrepreneurship in the countryside, etc., it is necessary to use comprehensive assessment.

This assessment is based on the use of scores, the significance of the criteria used for it and an aggregate of indicators:

$$
\text { EntreComp }=\sum_{i=1}^{n}\left(\lambda_{i} \cdot \alpha_{i j} \cdot \beta_{i}\right)
$$

where:

EntreComp - a complex assessment of the level of entrepreneurial competence of the person;

$\lambda_{i}-$ weight of the category in assessing the level of entrepreneurial competence of a person;

$\alpha_{i j}-$ points that put the experts in line with the person being evaluated;

$\beta_{i}-$ significance of the used criteria;

$i$ - competence;

$j$ - expert;

$n$ - number of evaluated competencies.

In the role of criteria $\left(\lambda_{i}\right)$ for the assessment of competencies, it is suggested to use the indicators summarized in Table 1.

In this case, the weight of the evaluation criteria can be distributed as follows: weight of general indicators (competencies) - 0.4; weight of acquired indicators (competencies) - 0.6.

The practice of personnel management shows that the assessment of employees is successful in cases where methods and criteria are chosen depending on tasks, the situation, wishes of managers and coordinated with employees.

In this case, the task of assessing entrepreneurial competence is to identify those entrepreneurs who, taking into account the current state of the agrarian sector, will be able, using their knowledge and experience to improve rural areas, to start their own business by providing new jobs by investing in objects of industrial and social infrastructure. Therefore, the importance of acquired competencies - a result of perseverance, efforts in obtaining education, improving qualifications and the desire to raise the cultural level - must be higher than innate ones, which are often not used, or are used to a small extent.

It should be noted that the composition of indicators $\left(\beta_{i}\right)$ and their significance are not constant values.
They can be determined by experts who carry out such an assessment, depending on the specifics of the business direction, the activity of the enterprise, the importance and significance of those or other indicators in a particular industry, positions and management levels.

The resulting integral indicators of the level of entrepreneurial competence of a person are compared either with the average by industry direction, or by the maximum obtained values of the estimated. The results of the assessment allow us to develop the directions and measures to improve the process of forming entrepreneurial competence of employees, and, consequently, the quality of the workforce. The definition of the organization's needs in professionally qualified, competent employees involves the introduction of professional guidance and professional training and forecasting of personnel in the structural subdivisions of enterprises in the professional and qualification sections.

\section{CONCLUSIONS}

The results of the conducted research give ground to conclude that the competence of the entrepreneur provides the possession of the personality means and techniques that allow him/her to effectively organize personal and collective entrepreneurial activity. However, it is necessary to take into account the fact that the process of forming entrepreneurial competence is subjective and objective - each person produces his/her own attitude to economic, social and political realities, his/her own view of existing socio-economic relations and the prospects for their development, in some way outlining their role, status and own potential opportunities in the relevant sphere of public life.

In light of the above, it is believed that only the purposeful formation of entrepreneurial competence among the inhabitants of rural areas as well as the assessment of the achieved level of competence by the entrepreneur at a certain stage of his/her life will contribute to the full development of a personality that is ready to change and improve living conditions in the countryside, freely choose his/her way of life, proceeding from personal aspirations, abilities and qualities. 


\section{REFERENCES}

1. Balanovska, T.I., Gogulya, O.P. (2017). Osoblivosti formuvannya menedzheriv agrarnoïsferi $\mathrm{v}$ konteksti potreb suchasnogo rinku pratsi [Features of the formation of managers of the agrarian sphere in the context of modern labor market needs]. Global and National Problems of the Economy, 9, pp. 138-143. Retrieved from: http://global-national.in.ua/issue-19-2017.

2. Bilova, Yu. (2013). The concept and structure of the entrepreneurial competence of future specialists in economics. In: Proceedings Rivne State Humanitarian University "Updating the content, forms and methods of training and education in educational institutions". Vol. 7, pp. 15-17. Retrieved from: http://nbuv.gov.ua/ UJRN/Ozfm 201377.

3. Borshchevskyi, V., Mahas, V., Tsymbalista, N. (2017). Potentsial rozvitku I perspektividrodzhennya sil's'kikh teritoriy vumovakh suchasnikh reform [Development potential and prospects for the revival of rural areas in the context of modern reforms: a scientific and analytical report]. State Enterprise Institute of Regional Studies named after M.I. Dolyshnyi of the National Academy of Sciences of Ukraine, Lviv. Retrieved from: http://ird.gov.ua/irdp/p20170202.pdf.

4. BusinessViews (2017). 5 tehnologij kotorye povysjat effektivnost ukrainskogo agrobiznesa $v 5$ raz $[5$ technologies that will increase the efficiency of Ukrainian agribusiness by 5 times]. Retrieved from: http://businessviews.com.ua/en/tech/id/5-tehnologij-kotorye-povysjateffektivnost-ukrainskogo-agrobiznesa-v-5-raz-1701/.
5. EntreComp: The Entrepreneurship Competence Framework (2016). Retrieved from: http://publications. jrc.ec.europa.eu/repository/bitstream/JRC101581/lfna27939enn.pdf.

6. Gogulya, O.P. (2017). Suchasni aspekti upravlinnya pidriemnits'koyu diyal'nistyu sil's'kogospodars'kikh tovarovirobnikiv v umovakh globalizatsi rinku [Modern aspects of management of entrepreneurial activity of agricultural commodity producers in the conditions of market globalization]. Economics and Society, 11, pp. 184-188. Retrieved from: http://www.economyandsociety.in.ua/journal-11/18-stati-11/1206gogulya-op.

7. McConnell, K.R., Brue, S.L. (2003). Economics: Principles, Problems and Politics. 14th ed. INFRA-M, Moskva.

8. Maykovska, V.I. (2017). The Essence and the Structure of Future Specialists' Business Competence in Ukraine. Zhytomyr Ivan Franko State University Journal. Pedagogical, 1 (87), pp. 112-117.

9. Robles, L., Zarraga-Rodríguez, M. (2015). Key Competencies for Entrepreneurship. Procedia Economics and Finance, 23, pp. 828-832. https://doi.org/10.1016/ S2212-5671(15)00389-5

10. Wyrzykowska, B. (2016). Competency models and their use in practice. Naukovij Visnik Nacional'nogo Universitetu Bioresursiv i Prirodokoristuvannâ Ukraini. Ekonomika, Agrarnij Menedžment, Bìznes Vip, 247, pp. 32-44. Retrieved from: journals.nubip.edu.ua/index.php/Economica/article/.../7746. 